\title{
A Study of the Chinese Retaliatory Tariffs on Tree Nuts Industry of California
}

\author{
Srini Konduru, Serhat Asci \\ Department of Agricultural Business, California State University, Fresno, CA, USA \\ Email: skonduru@csufresno.edu, sasci@csufresno.edu
}

How to cite this paper: Konduru, S. and Asci, S. (2019) A Study of the Chinese Retaliatory Tariffs on Tree Nuts Industry of California. Theoretical Economics Letters, 9, 2747-2755.

https://doi.org/10.4236/tel.2019.98172

Received: October 7, 2019

Accepted: November 22, 2019

Published: November 25, 2019

Copyright $\odot 2019$ by author(s) and Scientific Research Publishing Inc. This work is licensed under the Creative Commons Attribution International License (CC BY 4.0).

http://creativecommons.org/licenses/by/4.0/ (c) (i) Open Access

\begin{abstract}
The objective of this study is to analyze the economic impact of Chinese retaliatory tariffs on California's economy using the Input-Output model. Our model uses state level Impact Analysis for Planning (IMPLAN) dataset along with data from the United States Department of Agriculture-Foreign Agricultural Service (USDA-FAS), California Department of Food and Agriculture, and County Ag Commissioner's reports. The analysis focuses on the implications of the retaliatory tariffs by China in a scenario where the demand from other alternate export markets does not change. The results show that the tree nut industry's total output decreases by about $14 \%$ and $10 \%$ in the short-run and long run period respectively when compared to the baseline scenario. The tree nut sector would be employing about three thousand people lesser than the baseline scenario in the short-run period and about two thousand people in long-run period, which is equivalent to $7 \%$ in the short-run and $5 \%$ in the long-run period. The study concludes that it is very important for the US and China to resolve their trade disputes as quickly as possible in order to bring confidence not only to the tree nut industry in California, but hundreds of other industries that have been impacted by this trade war.
\end{abstract}

\section{Keywords}

Chinese Retaliatory Tariffs, Tree Nuts, California, Input-Output Model, IMPLAN

\section{Introduction}

In April 2018, the Chinese government has imposed tariffs on various US products, which included 93 agricultural products in retaliation to US tariff actions on Chinese products [1]. This is bound to impact the US agricultural sector as 
China is the second largest export market after Canada in 2017 [2]. Among the various agricultural products exported to China by the United States, tree nuts constitute the third most important category of products after soybeans and corn [2]. Almost all the major tree nuts (almonds, walnuts, pistachios) that are exported by the United States to China are from the state of California.

The Chinese retaliatory tariff of about $15 \%$ on tree nuts imported from the United States is bound to impact the California's economy where tree nuts are significant in terms of gross farm value and employment generation. Almond industry alone creates almost 100,000 jobs in the state of California [3]. In lieu of the retaliation by China, fears have been expressed in various popular news outlets that the Chinese retaliatory tariffs are going to adversely impact the economy of California especially in the Central Valley. Many studies in recent times analyzed the impact of the Chinese retaliatory tariffs on the US agricultural products and on the welfare of different stakeholders [4] [5] [6]. However, none of the studies analyzed the impact at a statewide economy level.

The objective of this study is to analyze the economic impact of Chinese retaliatory tariffs on California's economy, where tree nut (almonds, walnuts, pistachios) industry is concentrated. Along with analyzing the economic impact on producers, this study also focuses upon the impact on the overall economy of the state of California. The analysis focuses on the implications of the retaliatory tariffs by China in a scenario where the demand from other alternate export markets does not change. In other words, this study assumes all the other export market factors that can impact the export demand for tree nuts are held constant. This study analyzed the impact using the Input-output model. The model uses state level Impact Analysis for Planning (IMPLAN) dataset along with data from the United States Department of Agriculture-Foreign Agricultural Service (USDA-FAS), California Department of Food and Agriculture (CDFA), and County Ag Commissioner's reports to show significant economic and employment shifts in the state of California. Next Chapter explains the importance of California's tree nut industry followed by description of methodology and the IMPLAN model in Section 3. The results are discussed in Section 4 and the last section concludes with model limitations and policy recommendations.

\section{Tree Nut Industry in California}

\subsection{Importance of Chinese Market for Tree Nut Industry in California}

Tree nuts like almonds, pistachios and walnuts generate about one-sixth of the farm revenue in California. About $\$ 7.3$ billion worth of tree nuts has been exported from California in the year 2017 [7]. A major proportion of the production ends up in foreign markets. About $68 \%$ of almonds, $78 \%$ of pistachios and $65 \%$ of walnuts produced in 2017 were exported to foreign markets. Among the various export markets, China is the third largest market for California agricultural exports by value, worth about $\$ 2.2$ billion in 2017 , constituting $11 \%$ of total 
Ag exports (Figure 1). Among the various agricultural products exported to China by the United States, tree nuts constitute the third most important category of products after soybeans and corn [2]. Data from CDFA export database shows that about $11 \%$ of almond exports, $6 \%$ of walnut exports and $45 \%$ of pistachio exports ship to the markets of China/Hong Kong (Table 1). California is the sole origin of all these tree nuts that are exported. The export value of Almonds, Pistachios and Walnuts to China constitute $55 \%$ of total California agricultural exports destined to China.

\subsection{Importance of Tree Nut Industry to California}

The tree nut industry plays an important role in California agriculture. According to a study sponsored by the Almond Board of California, the almond industry alone contributed about $\$ 21.5$ billion in economic output which includes direct, indirect and induced outputs. The same study estimated that about 104,000 jobs are generated by almond industry, of which 68,000 jobs are due to almond farming including direct, indirect and induced jobs associated with almond

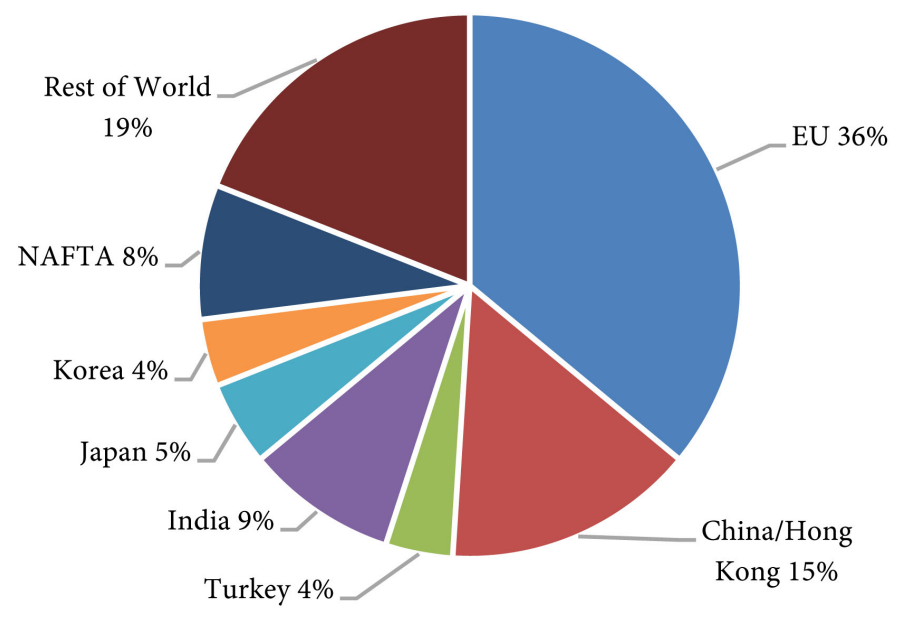

Figure 1. US Tree nuts export by destination in value share (2015-2017). Source: USDA FAS, 2018 [2].

Table 1. Importance of Chinese market to tree nut industry in California.

\begin{tabular}{cccc}
\hline & \multicolumn{3}{c}{ Total Exports } \\
\cline { 2 - 4 } \$ Millions & 2015 & 2016 & 2017 \\
\hline Almonds & 5143 & 4497 & 4483 \\
Pistachios & 848 & 1145 & 1518 \\
Walnuts & 1485 & 1342 & 1370 \\
& & Exports to China & \\
Almonds & $529(10 \%)$ & $518(12 \%)$ & $501(11 \%)$ \\
Pistachios & $178(21 \%)$ & $531(46 \%)$ & $663(44 \%)$ \\
Walnuts & $144(10 \%)$ & $78(6 \%)$ & $64(5 \%)$ \\
\hline
\end{tabular}

Source: CDFA annual reports, 2018 [7]. 
farming, and the remaining 36,000 jobs are associated with the direct, indirect, and induced economic activity of the processing and manufacturing sectors [3]. The total value of almonds grown in the state of California in 2017 is $\$ 5.6$ billion. Almond production is expected to increase in the coming years due to increased acreage and better prices in general. Although the price of almond was fluctuating over the last few years, the demand from Western European and Asia-Pacific markets is expected to remain strong unless the retaliatory tariffs prove to be otherwise.

Another important tree nut grown in California is walnut, which ranks as seventh most important crop in terms of value. The total walnut cash receipts for 2017 is about $\$ 1.6$ billion in 2017 [7]. The third important tree nut that is grown in California is pistachios, ranking among the top ten agricultural commodities by value with an estimated value of about $\$ 1.01 \mathrm{~b}$ [7]. Pistachios generate more than 22,000 jobs in California and value of the economic impact is approximately $\$ 3.6$ billion [8].

The tree nut industry contributes to the economy in different ways. Production of tree nuts, handling and processing of tree nuts and manufacturing of products based on tree nuts can be considered as three different ways by which tree nut industry generates economic activity and creates jobs in the Central Valley of California (Figure 2). Apart from the direct benefits that tree nut industry provides to the economy of California, there are many other supporting industries that create additional economic activity. Tree nut industry links with the economy of California in various ways to generate income and jobs. Crop input industries, crop service industries, and food service and retail industries that sell products with tree nuts, come under this category.

\section{Data and Methodology}

\subsection{Data}

This study uses an economic impact analysis, focusing on the export value of California's tree nut industry in 2017 in terms of its output, value added, and employment to test the hypothesis that retaliatory tariffs imposed by China will have a negative impact on California's economy in many sectors. In the first

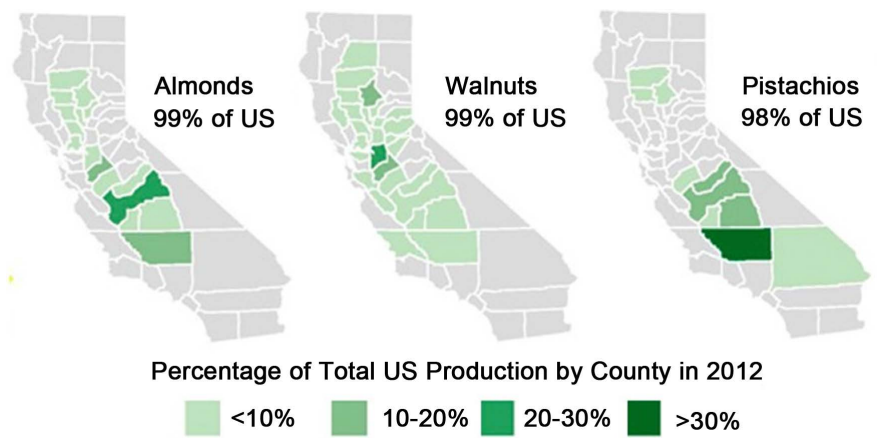

Figure 2. Tree nuts production in California by Counties and their magnitudes in US (2012). Source: USDA NASS, 2018 [9]. 
step, we employ a quantitative analysis to simulate possible changes in trade values due to the retaliatory tariff rates applied by China on US tree nuts industry. We utilize statistical relationship between the California's economy and tree nut exports in short run and long run. Production values, export, and demand and supply elasticities for selected tree nuts are collected for the simulation from USDA-FAS, California Department of Food and Agriculture, and Commodity Board reports. The elasticities show the percentage change in U.S. supply or employment that occurs from a one percent change in U.S. tree nuts export prices in either the short-run or long-run period.

\subsection{Input-Output Model}

Input-output model is applied in the IMPLAN (Economic Impact Analysis for Planning) software, which utilizes county and state level data to assess the effects of economic activities. IMPLAN combines publicly available industry output and employment data, etc. We add scenario simulation results into IMPLAN to determine the impact that tree nuts exports have on California's economy. IMPLAN model reports the direct, indirect, and induced effects. The direct effects are the primary economic activities measured that are impacted by the reduction in exports. The primary activities impact associated input industries such as chemicals, equipment and materials used in producing and handling tree nuts. IMPLAN data specify these effects through multipliers which are called as indirect effects. The model further traces the effects of changes in employment and total industry income which indicates the induced effects of the primary and associated economic activities in the state economy [10]. In summary, the model looks into how a dollar gain or loss in an industry within a region adjusts all economic activities as it moves along the economy [11]. In Table 2, the baseline scenario is given in which the tree nuts industry of California is a very small component of the total economy of California but will have significant impact on certain areas of California where agriculture is predominant.

The IMPLAN model calculates multipliers based on consumption or production activities of each stakeholder in the regional economy [3]. The economic impact is found with multipliers relating to the direct, indirect, and induced effects. The summation of these three economic measures informs us the impact of the tree nut industry on the whole of the California economy. We focused on three types of economic effects reported in IMPLAN analyses: the impact on

Table 2. Comparison of employment, total output and total value added generated by total economy of California and tree nut industry of California (Baseline Scenario).

\begin{tabular}{ccc}
\hline & Total Economy & Tree Nut Industry \\
\hline Employment & $23,572,469$ & 43,066 \\
Total Output (\$ billions) & 4428 & 8.47 \\
Total Value Added (\$ billions) & 2769 & 4.94 \\
\hline
\end{tabular}

Source: IMPLAN Database, 2017 [10]. 
employment, which is the change in the number of jobs (both full-time and part-time); and the impact on output, which is the change in the total spending; and the impact on value-added as the return to resources used by the industries. Since the labor income effect is a subset of value added measure, we did not report them in the result section. Because of the reduction in production levels of pistachios in the rest of world during 2017-18, the US pistachio exports to China did not get affected in the year 2018-19. In fact, there was a slight increase in the imports from the US GAIN Report [1]. Therefore, we have not analyzed the impact of retaliatory tariffs on pistachio industry.

\section{Results}

The price or revenue loss to almonds and walnuts due to retaliatory tariffs by China are shown in Table 3. The price decrease has been calculated using estimates of price elasticity of supply of almonds and walnuts [12]. The results are induced into input-output model to estimate both the short-run and long-run economic changes on California's total output and employment generated by tree nut industry. Results of the retaliatory tariff scenario are compared with the baseline scenario estimates of employment created and total economic output of California. The baseline year that is chosen for this analysis is 2017. At this stage, it is important to get reminded that this study was performed under the assumption that other demand from alternate export markets remains unchanged/constant.

The results of the input-output analysis are shown in Table 4. The direct revenue loss of tree nut industry (almonds \& walnuts) in California due to retaliatory tariffs is $\$ 602$ million in short-run period and $\$ 410$ million in long-run period. By adding the indirect and induced effects, the impact on total output of California is about $\$ 1179$ million in short-run period and $\$ 803$ million in long-run period. Tree nut industry's total output decreased by $14 \%$ and $10 \%$ when compared to the baseline scenario (see Table 2) in the short-run and long run periods respectively. The impact is lower in the long-run period as it gives time to the tree nut exporters to find alternatives to the Chinese markets whose market size would have become smaller. If we analyze the direct effect, the impact

Table 3. Price/revenue loss due to retaliatory tariffs on tree nut imports by China.

\begin{tabular}{lccccc}
\hline & $\begin{array}{c}\text { Exports to } \\
\text { China } \\
\text { 2017-18 } \\
\text { (million lb) }\end{array}$ & $\begin{array}{c}\text { Exports to } \\
\text { China } \\
\text { 2018-19 } \\
\text { (million lb) }\end{array}$ & $\begin{array}{c}\text { Change in } \\
\text { Exports to } \\
\text { China } \\
\text { (million lb) }\end{array}$ & $\begin{array}{c}\text { As a \% of } \\
\text { Total Supply }\end{array}$ & $\begin{array}{c}\text { \% Change in } \\
\text { Price } \\
\text { (Calculated) }\end{array}$ \\
\hline Almonds & 158.6 & 106.6 & -67.2 & -2.01 & -4.16 (short-run) \\
Walnuts & 19.3 & 7.4 & -4.7 & -3.57 & -23.3 (short-run) \\
& & & & & -18.4 (long-run) \\
\hline
\end{tabular}

Source: Data from Almond Board [13] and Walnut Commission [14], authors calculations. Notes: 1) Elasticity of Supply for Almonds: SR 0.24; LR 0.07; 2) Elasticity of Supply for Walnuts: SR 0.15; LR 0.19 [12]. 
Table 4. Impact of retaliatory tariffs on tree nut industry of California.

\begin{tabular}{ccc}
\hline & Short-run Period & Long-run Period \\
\hline Employment & -7585 & -5166 \\
Direct Effect & -2997 & -2041 \\
Indirect Effect & -2634 & -1794 \\
Induced Effect & -1953 & -1330 \\
& $\$$ Millions & \\
Total Output & $-\$ 1179$ & $-\$ 803$ \\
Direct Effect & $-\$ 602$ & $-\$ 410$ \\
Indirect Effect & $-\$ 245$ & $-\$ 167$ \\
Induced Effect & $-\$ 332$ & $-\$ 226$ \\
Total Value Added & $-\$ 729$ & $-\$ 496$ \\
Direct Effect & $-\$ 350$ & $-\$ 238$ \\
Indirect Effect & $-\$ 173$ & $-\$ 118$ \\
Induced Effect & $-\$ 206$ & $-\$ 140$ \\
\hline
\end{tabular}

is much smaller. Due to the direct effect, the total output decreased by $7 \%$ in the short-run and $5 \%$ in the long run period. Similarly, due to direct, indirect and induced effects, the Total Value Added (TVA) decreased by $\$ 729$ million in short-run period and by $\$ 496$ million in the long-run period. If we take only the direct effect on tree nut industry, the TVA decreased approximately by $7 \%$ in the short-run period and $5 \%$ in the long run period compared to the baseline scenario.

The employment generated by the economy of California would be lesser then the baseline period by 7585 jobs in short-run period and by 5166 jobs in the long-run period. It is important to observe that the direct impact on tree nut industry is lesser then the indirect and induced impacts on the other sectors of the economy. The tree nut sector would be employing about three thousand people lesser than the baseline scenario in the short-run period and about two thousand people in long-run period, which is equivalent to $7 \%$ in the short-run and $5 \%$ in the long-run period.

\section{Conclusions}

The retaliatory tariffs imposed by China would impact the California's tree nut sector significantly. The results show that the tree nut industry's total output decreases by about $14 \%$ and $10 \%$ in the short-run and long run period, respectively. The results also indicate that the employment in the industry would reduce $7 \%$ in the short-run and 5\% in the long-run period. Our study is bound by a few limitations, some of which are associated with the usage of the IMPLAN software. The limitations of IMPLAN are that the model is static, which means the relationships in a given year do not change and are not affected by impact runs. 
The model operates on constant returns to scale and no supply constraints built into it. Along with listed IMPLAN based limitations, our study also utilizes elasticity estimates from studies published a few years back. Revised estimates of elasticity would definitely capture the latest consumer attitudes towards tree nut consumption.

The study shows that the sum of indirect and induced effects on the total economy of California is much higher than the direct effects on the tree nut industry. As China is a major market, if the retaliatory tariffs continue or worsen over the time, the tree nut industry in California would have to look for alternative export markets in order to sustain and preserve its role in the agricultural sector of California. It is also important to understand that the consumers in China are also going to be impacted due to higher prices of tree nuts and their products due to the retaliatory tariffs. The implications of such a scenario can be manifold. There might be a lot of rerouting of China bound shipments to Hong Kong, as importers might want to utilize the informal trade routes that exist between Hong Kong and China, thereby bypassing the tariffs. We witnessed that many Californian traders have finalized their deals earlier than usual as the retaliatory tariffs were in place for some time. They might have escaped the tariffs this year, but if they persist, this ploy may not work again. If the tariffs persist or increase in the future, consumers in China would be subjected to higher prices in the future or shift to alternatives products to tree nuts as there is no other major country that can take the place of the US as top tree nut exporter. For the US based exporters, presently the markets of EU and India are providing alternatives to Chinese market, however, India is also enacting higher retaliatory tariff regime for tree nuts recently. Therefore, in this highly volatile and unstable trading scenarios, it is very important for the US and China to resolve their trade disputes as quickly as possible in order to bring confidence not only to the tree nut industry in California, but also to hundreds of other industries that have been impacted by this trade war.

\section{Conflicts of Interest}

The authors declare no conflicts of interest regarding the publication of this paper.

\section{References}

[1] USDA FAS Gain Report (2018) China Responds to U.S. Section 301 Trade Action Announcement. U.S. Department of Agriculture, Foreign Agricultural Service, Gain Report CH18018, April 2018, Washington, DC.

[2] USDA FAS (2018) Top Agricultural Exports in 2017. https://www.fas.usda.gov/data/top-us-agricultural-exports-2017

[3] Sumner, D.A., Matthews, W.A., Medellín-Azuara, J. and Bradley, A. (2014) The Economic Impacts of the California Almond Industry. The Almond Board of California. University, California, Davis, CA.

https://aic.ucdavis.edu/almonds/Economic\%20Impacts\%20of\%20California\%20Al 
mond\%20Industry Full\%20Report FinalPDF v2.pdf

[4] Taheripour, F. and Tyner, W. (2018) Impacts of Possible Chinese 25\% Tariff on U.S. Soybeans and Other Agricultural Commodities. Choices, 33, 1-7.

[5] Sumner, D.A. and Hanon, T.M. (2018) Economic Impacts of Increased Tariffs That Have Reduced Import Access for U.S. Fruit and Tree Nuts Exports to Important Markets. Agricultural Issues Center, UC Davis.

[6] Sabala, E. and Devadoss, S. (2019) Spatial Equilibrium Analysis of Chinese Tariff and Yuan Devaluation on World Cotton Markets. The Western Agricultural Economics Association, Coeur d'Alene, Idaho.

[7] California Department of Food and Agriculture (CDFA) (2018) NASS/CDFA Agricultural Resource Reports. California Agricultural Production Statistics. https://www.cdfa.ca.gov/statistics/

[8] American Pistachio Growers (APG) (2018) Economic Impact of California Pistachios. https://www.apgpower.org/economic-impact-report/

[9] USDA NASS (2018) Quick Stats. Production by California Counties. https://quickstats.nass.usda.gov/

[10] IMPLAN Group, LLC. (2017) IMPLAN Database. Huntersville, NC. IMPLAN.com.

[11] Williams G.W., Capps Jr., O. and Hanselka, D. (2017) The National Economic Benefits of Food Imports: The Case of U.S. Imports of Hass Avocados from Mexico. Journal of International Food \& Agribusiness Marketing, 29, 139-157. https://doi.org/10.1080/08974438.2016.1266570

[12] Russo, C., Green, R.D. and Howitt, R.E. (2008) Estimation of Supply and Demand Elasticities of California Commodities. Agriculture and Resource Economics Working Papers, Department of Agricultural and Resource Economics, UCD, UC Davis, 128 p. https://doi.org/10.2139/ssrn.1151936

[13] Almond Board (2019) Nass Crop Forecasts and Acreage Reports. Almond Board Crop and Acreage Reports.

https://www.almonds.com/growers/resources/crop-forecasts/tc-NASS-Crop-and-A creage-Reports

[14] Walnut Commission (2019) Acreage and Crop Estimate Reports. Reports. https://walnuts.org/walnut-industry/reports/ 